\section{International Scientific Journal Theoretical \& Applied Science}

p-ISSN: 2308-4944 (print) e-ISSN: 2409-0085 (online)

Year: $2014 \quad$ Issue: $10 \quad$ Volume: 18

Published: $30.10 .2014 \quad$ http://www.T-Science.org
Elena Vladimirovna Akutneva

candidate of agricultural Sciences, associate Professor of the Department of «Land management and land cadastre» Volgograd state agricultural University, Russia akutneva@inbox.ru

SECTION 23. Agriculture. Agronomy. The technique.

\title{
APPLICATION SUBSOIL IRRIGATION IN FRUIT GROWING
}

Abstract: Questions irrigate fruit crops are the least studied compared with other crops. Important reserve of gardening is to develop new high-performance and cost-effective methods of irrigation and improvement of existing irrigation methods. Considerable interest from the perspective of the development of irrigation is subsurface irrigation method. Experiments in the Russian Federation and CIS countries established a number of positive qualities of this method of watering. It creates favorable conditions for the occurrence of microbiological processes in the soil, which provides a quantitative and qualitative improvement of the crop.

Key words: methods of irrigation, subsurface irrigation, fruit crops.

Language: Russian

Citation: Akutneva EV (2014) APPLICATION SUBSOIL IRRIGATION IN FRUIT GROWING. ISJ Theoretical \& Applied Science 10 (18): 41-44. doi: http://dx.doi.org/10.15863/TAS.2014.10.18.10

\section{ПРИМЕНЕНИЕ ВНУТРИПОЧВЕННОГО ОРОШЕНИЯ В ПЛОДОВОДСТВЕ}

Аннотация: Вопросы орошения плодовых культур остаются наименее изученными по сравнению с другими сельскохозяйственными культурами. Важным резервом развития садоводства является разработка новых высокоэффективных и экономичных способов орочения и совериенствование существующих способов полива. Значительный интерес с точки зрения перспектив развития орошения представляет внутрипочвенный способ полива. Опытами в Российской Федерачии и странах СНГ установлен ряд положительных качеств такого способа полива. Оно создает благоприятные условия для протекания микробиологических прочессов в почве, что обеспечивает количественное и качественное повышение урожая.

Ключевые слова: способы полива, внутрипочвенное орочение, плодовые культуры.

Современные способы и техника полива должны обеспечивать создание оптимальных условий для выращивания плодовых культур; способствовать сохранению структуры почвы; проведению поливов с минимальным расходованием оросительной воды на единицу площади; получению высоких урожаев с хорошим качеством плодов; препятствовать возникновению водной эрозии; механизировать и автоматизировать процесс полива; регулировать в определенном диапазоне водный, питательный и воздушный режимы почвы и растений; повышать степень надежности и коэффициент полезного действия оросительных систем; уменьшать энергетические затраты [4,7]. Благодаря большому сроку службы, внутрипочвенное орошение характеризуется высокой экономической эффективностью при орошении многолетних культур, таких как плодовые культуры [9].
Расстояние между увлажнителями для садов и виноградников зависит от расстояния между рядами посадок. Для новых насаждений целесообразно закладывать 1 - 2 увлажнителя в ряду сада или виноградника. В существующих садах и виноградниках увлажнитель следует закладывать на расстоянии 1,5 - 2,0 м от оси ряда [5]. На среднесуглинистых и глинистых почвах для плодовых насаждений первый увлажнитель рекомендуют закладывать на расстоянии 1,5 1,75 м от штамба дерева, а последующие - через $2,5-3,5 \mathrm{M}$.

Исследования по применению внутрипочвенного орошения в плодоводстве проводились и проводятся в настоящее время, как в России, так и зарубежом.

В Калифорнии еще в XIX веке для орошения садов применялся способ Ли, который осуществлялся следующим образом. Закладывалась главная магистраль (труба) 
диаметром 0,15 м она подводила воду к саду, к ней присоединялись боковые отводы диаметром 0,07 м, расположенные под почвой вдоль ряда деревьев. Около каждого дерева имелся клапан, через который увлажнялась почва [3].

С 1963 года в совхозах винкомбината «Масандра» Херсонской области УкрНИИГиМом [6] проводились исследования по внутрипочвенному орошению виноградников на крутых склонах. В ходе исследований изучали технику внутрипочвенного полива и его эффективность. Расстояние между увлажнителями устанавливалось в зависимости от уклона местности и водоупора. Длина увлажнителей из керамических труб диаметром 60 мм составляла 50 м. Вода в увлажнитель поступала под напором $0,2-0,25$ м с расходом 1 - 1,3 л/с, поливы проводили малыми поливными нормами (до $22 \mathrm{~m}^{3} /$ га) один - два раза в неделю. В результате было установлено, что на горных склонах внутрипочвенное орошение обеспечивает удовлетворительное увлажнение почвы и повышает урожайность ягод винограда в 2 - 2,5 раза по сравнению с неорошаемым участком.

На Курской зональной опытномелиоративной станции ВНИИГиМ с 1966 года проводились исследования по внутрипочвенному орошению садов [5], при этом было запроектировано два опытных участка. На участке площадью 0,25 га с уклоном 0,002 - 0,03 использовали внутрипочвенные увлажнители из перфорированных полиэтиленовых труб диаметром 50 мм. Перфорации были выполнены в виде круглых отверстий диаметром $8-10$ мм с шагом через 0,1 - 0,12 м и расположены в один ряд. На опытном орошаемом участке площадью 3 га применялись увлажнители из пластмассовой упругой пленки толщиной 0,5 - 0,8 мм. Из - за отсутствия специальных машин для прокладки увлажнителей, строительство проводилось бестраншейным дреноукладчиком ДПБН - 1,8 конструкции Мещерской ЗОСМ ВНИИГиМ, предназначенного для прокладки дрен в целях осушения легких торфяных грунтов. Расстояние между увлажнителями составляло 2 м, глубина укладки 0,4-0,5 м, длина - 200 м.

В процессе определения контуров увлажнения было выявлено, что основное увлажнение происходит в слое почвы на глубине $0,2-1,5$ м, а в двухметровом слое оно несколько уменьшается. Смыкание контуров было достигнуто при поливных нормах $700-900 \mathrm{~m}^{3} / г$. При испытываемой протяженности увлажнителя и расходе 1,4 л/с наблюдалось равномерное распределение воды по всей его длине. Для поддержания влажности почвы на уровне $80 \%$ НВ в среднесухие годы проводилось два полива нормой $800-900 \mathrm{~m}^{3} /$ га, в сухие годы три полива поливной нормой $1400-1800 \mathrm{~m}^{3} /$ га, а также во все годы предусмотрен осенний влагозарядковый полив нормой $700-800 \mathrm{~m}^{3} /$ га. В результате этого все деревья имели хороший вегетационный прирост и при экономном расходовании воды ежегодно стали давать устойчивые и высокие урожаи (в среднем за 4 года исследований 12 т/га).

Использование пластмассовых материалов при строительстве систем внутрипочвенного орошения позволило снизить капитальные затраты в 2 раза по сравнению с участком с увлажнителями из гончарных трубок, а также почти полностью автоматизировать полив [5].

Эффективность применения внутрипочвенного орошения в плодоводстве доказывают и исследования Кременского В.И. [2], которые проводились с 9 - летними яблонями сорта Голден Делишес [85]. При этом использовали перфорированные внутрипочвенные увлажнители, заложенные на глубину 0,8 м и смещенные вправо на 0,05 м относительно штамба дерева. Исследования характера распределения корневой системы показали, что в результате внутрипочвенной подачи воды вокруг увлажнителя образуется большое количество обрастающих корней, которые располагаются параллельно увлажнителю. Проникновение корней в увлажнитель через отверстия перфораций не наблюдалось, что подтверждает возможность использования исследуемой системы внутрипочвенного орошения при поливе плодовых культур.

Проведенные исследования систем внутрипочвенного орошения на виноградниках в совхозе «Гратиешты» Молдавской ССР привели к увеличению урожая по отношению к контролю без полива в 2 - 2,7 раза [5]. Орошение проводили макрокапиллярной системой внутрипочвенного орошения, с укладкой увлажнителей через 1 - 4,5 м на глубину 0,7 м. внутрипочвенные магистрали располагали на расстоянии 0,3 - 0,4 м от штамба дерева. Равномерность увлажнения почвы по длине увлажнителей достигалась компенсацией пьезометров различным количеством фильтрующих отверстий в трубках - питателя.

С 1971 по 1974 г. сотрудниками отдела внутрипочвенного орошения НИСТО и отдела техники орошения САНИИРИ проводились исследования по орошению неплодоносящего виноградника и сада яблонь, сливы и айвы системой внутрипочвенного автоматического полива на основе пористых очаговых увлажнителей с клапанами, подключенными к трубопроводной распределительной сети из полиэтилена [5]. Систему внутрипочвенного 
орошения испытывали в условиях пересеченной местности под Ташкентом на средне- и тяжелосуглинистых почвах. Очаговые увлажнители цилиндрической формы из пористого пластораствора устанавливались непосредственно у корневой системы растений. Количество опытных водовыпусков было различным (15 - 24 шт.). Закладывались увлажнители на глубину 0,55 - 0,60 м, а напоры воды в них поддерживались в пределах 0,2 - 0,22 м. Саженцы яблонь, айвы, сливы располагали в одном створе от водовыпуска на расстоянии 0,5 ; 1,$0 ; 1,5 ; 2,0$ м, а затем, чтобы исключить или ослабить взаимное влияние, саженцы размещались по спирали относительно водовыпуска.

В ходе исследований была отмечена высокая надежность работы изучаемой системы внутрипочвенного орошения и даны следующие рекомендации по укладке увлажнителей. На существующих посадках сада, с целью наименьшего повреждения корневых систем растений, внутрипочвенная оросительная сеть должна располагаться не ближе 2 м от оси основного ряда деревьев. Для саженцев оптимальное расстояние между местом посадки и водовыпуском составляет $1-1,5$ м. Располагать водовыпуски ближе 0,5 м нежелательно. Это связано с трудностями строительства и последующего ухода за сетью в эксплуатационный период. Более удаленное расстояние от саженцев (2 м) приводит к недостаточному увлажнению почвы и, как следствие этого, к остановлению в росте растений в первый год посадки с заметными отличиями в последующем развитии. Основные результаты проведенных исследований представлены в работах В.Н. Лунева, Л.Х. Ким, В.М. Масленникова, А.П. Орлова, Я.Хондрояниса [2].

В винсовхозе «Абрау-Дюрсо» Краснодарского края с 1978 по 1984 г. проводились исследования на опытнопроизводственном участке внутрипочвенного орошения ВГСХА на площади 2,4 га [2]. Увлажнители из гончарных трубок диаметром 50 мм и гофрированных полиэтиленовых перфорированных труб диаметром 44 мм с 200 отверстиями диаметром 1 мм на 1 п.м. были заложены на глубину 0,5 м с уклоном 0,0680,071. предложена конструкция внутрипочвенного увлажнителя с плавающим наполнителем. В результате исследований доказано, что внедрение внутрипочвенного способа полива позволяет сократить затраты труда при возделывании виноградников в 2,4 раза, срок окупаемости затрат на строительство составил 1 год. Урожайность винограда на участке составила 14,41 т/га, без орошения - 4,69 т/га.

В Чехословацком НИИ орошаемого земледелия [8] для орошения плодовых культур и винограда разработана автоматизированная система внутрипочвенного орошения с гофрированными полипропиленовыми трубками-увлажнителями внутренним диаметром 23 мм и толщиной стенок 0,4-0,5 мм. Увлажнители закладывались на глубину 0,45 м, рабочий напор 0,25 - 0,5 м. Продолжительность полива 6 - 10 часов при интенсивности водоподачи в корневую зону почвы 1,5 - 2,0 мм/ч на 1 га. Использование такой системы повышает эффективность водораспределения, снижает затраты труда, воды, энергии и капиталовложений.

В 1992 г. в фермерском хозяйстве СКХ «Садовод» Михайловского района Волгоградской области был построен опытный участок внутрипочвенного орошения площадью 2,5 га. Увлажнители из трубки ПВХ с внутренним диаметром 100 мм и точечной перфорацией через 0,2 м уложены на глубину 0,5 м от штамба дерева. Увлажнители соединены муфтами из полиэтиленовой пленки, во избежание заилений отверстий они обертывались стеклохолстом. Расстояние между увлажнителями 6 м.

Опыты проводились с 6 - летними яблонями сорта «Северный Синап», «Голден Делишес», «Ренет Курский Золотой», «Джоноред», «Память Мичурина» и «Корт Ланд». В ходе исследований выявлено, что для нормального роста, развития и плодоношения сада необходимо создание оптимальных условий водообеспеченности метрового слоя почвы. Длина активных и переходных корней при внутрипочвенном орошении была в среднем на 10 - 12\% выше по сравнению с поливом по бороздам. В 1988 г. при внутрипочвенном орошении сад вступил в фазу плодоношения. Средняя урожайность с дерева на различных сортах составила от 28 до 34 кг, а на орошении по бороздам и богаре урожая практически не было [2].

В 1993 г. в ОАО «Сады Придонья» Городищенского района Волгоградской области был заложен опытный участок..

Оросительная сеть участка проведения исследований, состояла из магистрального трубопровода $\mathrm{d}=0,40 \mathrm{M}$, к которому с помощью фланца присоединялась гребенка с тремя выходами из полиэтиленовых труб для наполнения водонапорных баков емкостью 4 м3 (имеющих автоматический регулятор напора поплавкового типа) и увлажнителей с внутренним диаметром $\mathrm{d}=34$ мм и длиной 150 м. В качестве увлажнителей были выбраны 
полихлорвиниловые трубы с полнооборотным полиэтиленовым экраном.

Укладка увлажнителей проводилась в ручную на расстоянии 1,2 м от ствола деревьев. Перфорация была выполнена с $\mathrm{d}=2$ мм и шагом 100 мм в обе стороны от штамба дерева. Длина перфорированного участка составила 2,4 м. Полнооборотный противофильтрационный экран выполнен из полиэтиленовой пленки шириной 0,4 м. Экран огибал увлажнитель и имел выход воды в сторону штамба дерева. Устройство экрана вызвано необходимостью сдерживать фильтрацию воды в нижележащие горизонты, и предотвращения заиления, а также увеличения контура увлажнения.

Опытный участок был заложен сортами Мелба, Оттава, Мантет на подвое М9. Посадка произведена по широкорядной уплотненной схеме 6 х 4 м, с густотой стояния 416 деревьев на гектар. Общая площадь опытного поля внутрипочвенного орошения 1,8 га.

Показатели роста яблони при внутрипочвенном орошении оказались выше в сравнении с поливом по бороздам. В зависимости от сорта длина ежегодных приростов яблони на 15 -21\%, диаметр кроны на 5-17 \%, диаметр штамба 8-27 \% больше, чем при поливе по бороздам. С увеличением возраста деревьев яблони отмечено увеличение средней массы плодов. У сорта Оттава она возросла на 64,5 \%, Мелба на 53,5 \%. Меньшее увеличение массы плода у сорта Мантет на 18,7 \% связано с наибольшей урожайностью яблок. Максимальная урожайность яблок при поддержании уровня предполивной влажности активного слоя почвы 70 \% НВ на участке внутрипочвенного орошения составила по сорту
Мелба 42,2 кг/дерево, по сорту Оттава 40,4 кг/дерево, по сорту Мантет 46,3 кг/дерево, что на $30-50 \%$ выше в сравнении с вариантом поверхностного орошения. При увеличении или снижении влажности почвы на $10 \%$ HB наблюдается статически достоверное снижение урожайности яблок (НСР05 =2,1 кг/дерево) [1].

Проведенные в Израиле в 90 - х годах $20-$ го века полевые исследования с применением внутрипочвенного и капельного орошения в грушевом саду показали возможность получения высоких урожаев при использовании для полива соленой воды [5]. Было выявлено, что распределение влажности при внутрипочвенном поливе лучше приспособлено к характеру распределения корней в почве по сравнению с традиционным капельным орошением.

Таким образом, многочисленные исследования показывают, что внутрипочвенное орошение оказывает благоприятное влияние на общее развитие плодовых деревьев, способствует уменьшению периодичности плодоношения, позволяет получать достаточно высокие урожаи с хорошим качеством плодов, повышает зимостойкость плодовых деревьев, способствует хорошей приживаемости их саженцев.

Однако, в связи с достаточно большими капиталовложениями на строительство систем внутрипочвенного орошения, необходимо проведение дальнейших исследований, направленных на уменьшение стоимости этих систем и увеличение их экономической эффективности путем совершенствования существующих конструкций систем внутрипочвенного орошения и методов расчета режима и техники полива.

\section{References:}

1. Akutneva EV (2005) Subsurface irrigation of an apple orchard in the conditions of the Volgograd region. Diss. on soisk. uch. Art. ksn, Volgograd.

2. Akhmedov AD, Borovoy EP, Gregory MS, Khodyakov EA (2000) Subsurface irrigation in the cultivation of forage crops. Ouch. benefits. Volgograd, 128.

3. Bagrov MN (1983) Ways rational and economical use of irrigation water. biological and cultural bases of irrigated agriculture. Moscow: Science, pp. 155-161.

4. Bagrov MN (1975) Crop irrigation regime. Overview. Moscow: TSBNTI Minvodkhoz, pp. 76.

5. Vetrenko EA (2003) Scientific and experimental validation of subsurface irrigation apple orchard. Diss. on soisk. uch. Art. Ph.D., Volgograd, pp.75-110.
6. Kozmenko AA (1968) Some production and biological characteristics of apple trees in a Volga-Akhtuba floodplain. Author. Candidate. diss. to the agricultural nauk. Volgograd, pp.411.

7. Listopad GE, Ivanov AF, Klimov AA, Filin VI (1979) Technology Guide programmed cultivation of grain and forage crops on irrigated lands of the Lower Volga. - Volgograd Agricultural Institute, pp. 15-17.

8. Skobeltsin YA, Gumbarov AD, Dubinin SV (1988) Subsurface irrigation of crops. - Kuban Krasnodar: Agricultural Institute, 93.

9. Sukhanov AF, Sobolev AV, Kapustin VI, Natalchug NF (1967) Watering the garden of pipelines. Hydraulic Engineering and Reclamation, No. 12, pp. 55. 